\title{
Assessment of the Role of Coding and Supervision to Minimize Academic Cheating in Case of Bonga University
}

\author{
Adissu Ketemaw (MA) \\ Bonga University Department Of Management, PO box 334 \\ Tezera Bekel (MPA) \\ Bonga University Department Of public administration and development, PO box 334
}

\begin{abstract}
The fundamental purpose of this action research is to determine ways of minimizing exam cheating by the two common method of cheating privation which are exam coding and closely supervision among second year management student in Bonga University. Census sampling was implemented as a sampling technique. Both primary data collected through observation and interview, and secondary data collected from the department report was used. Method of analysis and evaluation was carried out based on the comparison of the previous cheating recorded with the actual result after the proposed methods were implemented. Finally the researcher funded that student highly attempted in cheating but this strategy minimizes level of cheating compared to the pervious time. From this finding the researcher conclude that coding as exam cheating minimization mechanism plays a vital role. Keywords: exam cheating, coding and cheating minimization
\end{abstract}

DOI: $10.7176 /$ RHSS/10-9-02

Publication date:May $31^{\text {st }} 2020$

\section{I.Introduction}

Education quality is a paramount concern for countries all over the world. The problem is more severe in developing countries than in advanced ones for various reasons. Developed countries devise policies and guides on which they worked for years, insuring their implementation and measuring their effectiveness. The UNESCO [1] states countries such as Germany, France and Norway as the leading countries in educational quality. In times the already devised policies and other educational programs fail to meet the standard they were supposed to achieve, developed countries look for others and still keep working to solve the problem. Developing countries, on the other hand, have a long way to go for educational quality.

Today, a number of colleges and universities have taken additional steps to promote academic integrity by the use of an honor code that more often than not includes student responsibility for reporting known incidences of cheating. It appears that some of these honor code systems are successful in curtailing academic [2].

Educational quality is affected by several factors, one of which is cheating on exams [3].Deferent Studies indicate that students cheat on exams using different techniques which may not be noticed by the supervisors. Cheating methods change from time to time, and this is one reason why it is very difficult to avoid cheating. However, measures which can to be taken to make the problem lesser and to make students rely on themselves. Even though there are several measures of such kind already taken, the problems are prevalent in developing countries like Ethiopia.

Academic cheating is a common problem in academic institution in Ethiopia elementary, secondary, preparatory school and higher education universities. According to Asmara Teshome (unpublished paper) states in his finding that cheating practice are increasing with various tactic and also School management, teachers, students and parents have contribution for presence of the problems .

According to (Sarita and Dahiya) [4] reported the occurrence of frequent cheating in exams. Various factors contributing for the cause of cheating have been pointed out by various scholars. Grad point average, moral values, ambition and course grad have been reported as related factor for cheating.

As it has been discussed above cheating is a common practice in various exams. When we see previous year student disciplinary record exam cheating is serious problem in college of Business and Economics at Bonga University.

Various approaches have been proposed by different scholars to tackle this problems. Exam coding could also be used to control cheating and it is easy to employee it that doesn't require extra space or assessment class room and effort.

The fundamental purpose of this action research is to determine ways of minimizing exam cheating by the two common method of cheating privation among second year management student case of exam cheating. So, this study would help the department as well as the college to minimize the increasing number of students who are engaging themselves in academic cheating. This study would also serve as basis for future study plans of the college administrators for appropriate actions to be done in order to minimize cheating 
Hence, this study identified major cheating methods practiced in Bonga University. It also focused on the impact of coding and close supervision in exam in the case of collage of Business and economics department of Management second year students. Therefore, this action research designed to solve this problem with two research questions which are what is the role coding in minimizing cheating? and How much effective is closely supervision in reducing cheating?

\section{Literature Review}

\subsection{Concept of academic cheating}

Academic cheating is just signifying someone else's work as your own. Cheating (e.g., copying from another student in an exam) are forms of misconduct that have become areas of increasing concern for academics in higher education [5].

The characteristics associated with cheating divided into individual factors (gender, age, etc.) and environmental factors (pressure, self-confidence, reason for learning, etc.). Environmental factors are shown to have a greater predictive power for subsequent cheating. The particular questions that students encounter when deciding whether to cheat are what is my purpose? Can I do this task? And what are the costs associated with cheating [6].

\subsection{Empirical reviews in academic cheating}

According to Donald McCabe and the International Center for Academic Integrity, based on a survey of more than 70,000 students between 2002 and $2015,39 \%$ of undergraduate students confess cheating on a test, $62 \%$ of undergraduate students confess cheating on a written assignment, $68 \%$ of undergraduate students confess to cheating on either a test or written assignment [7].

Students high in anti-intellectualism attitudes and those with low academic self-efficacy were least likely to perceive college cheating as unethical. Cheaters, in courses in which they cheated, were also lower in mastery motivation and higher in extrinsic motivation than were no cheaters. Lastly, cheaters differed from non-cheaters on perceived social norms regarding cheating, on their knowledge of institutional policy regarding cheating, and on their attitudes toward cheating. Students' motivation, in particular whether they are studying to learn rather than simply to obtain good grades, is a major factor in explaining these differences [8]

Dishonesty is concern of several, but most students desire not to know or talk about it. In recent survey, $1 / 2$ of students surveyed believe the faculties in their university do not try to catch cheaters. New students find themselves in courses beyond their capability so they resort to cheating. For this reason, today there are a number of cheater students in the course of their secondary school and university studies. Cheating students have hence taken the behavior as ordinary and a way to a lucrative end. Currently in the country such survey data are not available but cheating practice is widespread. That's why this action research is designed to conduct [9].

\subsection{Methods of Cheating}

Academic cheating comprises of plagiarism, stealing tests, fabricating academic documents, purchasing term papers, or copying from someone's exams, and thus, most likely happen when students reproduce and submit the work of their peers, or allow other students to duplicate from their work during examination and homework settings [6].

The following are major cheating methods identified in this study and identified based on specific objectives this action research.

- Copy from others answer sheet.

- Write answer on their hands and exam paper

- Using short note and their handout

- Mobile phones used for sending texts

- Arranging stable condition for others to cheat

\subsection{Method of cheating minimization}

There are different cheating minimization methods; advice students, design appropriate studding style, monitor students before and during the exam, through appropriate sitting arrangement. As grasped from this study, it seems better if the university takes corrective measures on convincing students on bad aftermath of cheating in student's academic life in particular and societies at large with strong emphasis. To this effect the academic institution must design appropriate strategies comprehend to hold students accountable for any cheating case in which they might engage. It is very crucial to think over holistic approaches that will enable the university to overcome cheating case and produce self confident and competent professionals on open academic markets under real working environment [3]. 


\section{Research Methodology}

\subsection{The Study Area}

This action research study will be conducted at Bonga University on college of business and economies in department of management student second year student.

\subsection{Participants}

The target population for this study is instructors of Management department at Bonga University as well as all second year management students in management department. Therefore, all instructors which have course for first year student and all second year management students was the participant of this action research.

In these study censuses sampling technique was adapted because the participant for the study group is small and for the purpose of interviewing the invigilators and the course instructors. There were 9 invigilators and 6 course instructors. Therefore 9 invigilators and 6 course instructors was interviewed.

Different types of coding in exam for each course was prepared, and the exam paper were distributed to the student of Management section which are section A and section B student.

\subsection{Source of Data and Method of Data Collection}

The study were used both primary and secondary types of data. Primary data was collect from the instructor and invigilators through interview, and also from all second year management students through the way of observation during exam.

\subsection{Method of implementation and evaluation the study}

The author used the previous record of cheating and different method of cheating minimization material as acritrias for evolutions of the study and implemented those cheating minimization methods which identified in the proposed plan and compared it with the result found after implementing the strategies by observation of some of the examination rooms and by interviewing the invigilators and course instructors.

\section{Discussions and presentations of the study}

\subsection{Implementation}

The implementation of the identified mechanisms was carried out through informing All the course instructors and invigilators about the proposed strategies and implementation procedures and what have been expected from them. Especially on coding and shading of the exams for instructors, and methods of cheating, the strategies designed and the action to be taken for invigilators. These strategies carried out on three courses.

\section{Table 1: The courses of the exam which taken by second year management students}

\begin{tabular}{|c|c|c|c|}
\hline List of courses & $\begin{array}{l}\text { No } \\
\text { exams }\end{array}$ & $\begin{array}{l}\text { No of Exam rooms for Sec "A" and } \\
\text { "B" }\end{array}$ & $\begin{array}{l}\text { No of } \\
\text { invigilators }\end{array}$ \\
\hline Statistics for management II & 2 & 2 & 3 \\
\hline $\begin{array}{l}\text { Leadership and change } \\
\text { management }\end{array}$ & 2 & 2 & 3 \\
\hline Principles of marketing & 2 & 2 & 3 \\
\hline Total & 6 & 6 & 9 \\
\hline
\end{tabular}

During these exams, some students were attempted to cheat on the first two exams, but because of the cod of the exam and close supervision by the invigilators, and still the students become unsuccessful and also no other serious measurements were taken.

\subsection{Method of cheating and minimization}

There are different method of cheating such as Copy from others answer sheet, Write answer on their hands and exam paper, Using short note and their handout, Mobile phones used for sending texts and arranging stable condition for others to cheat. To prevent those method the researcher implement different cheating minimization methods; advice students, design appropriate studding style, monitor students before and during the exam, through appropriate sitting arrangement finally distributing the exam with code . As grasped from this study, it seems better if the university takes corrective measures on convincing students on bad aftermath of cheating in student's academic life in particular and societies at large with strong emphasis. To this effect the design appropriate strategies comprehend to hold students accountable for any cheating case in which they might engage.

\subsection{Evaluation of intervention}

The authors evaluated the effectiveness of the strategy to minimize cheating practice among second year management students, by using coding and direct supervision during examination and interviewing invigilators and course instructors. 


\subsubsection{Observation}

The researcher tried to observe the exam class, student's perception on exam with code as well as supervisions during their exam, the role of coding to minimize cheating and method of cheating practiced by the student during the exam. In addition to this we observed the exam class student as well as the invigilators during examination whether the exams were going according to the strategies we planned or not.

\subsubsection{Interviewing the invigilators}

At the end of each test we tried to communicate with invigilators to see if there was any cheating case or not and the action they took. The invigilators Saied that they had invigilated second year management students and they knew the student highly attempted in cheating but this strategy minimize level of cheating compared to the pervious time. In addition the invigilator had not caught a student who was cheating however the practice of cheating is not avoided, even the student know there was a cod on exam the supervision of the invigilators.

\subsubsection{Interviewing the course instructors}

Some attempt was made to communicate the course instructors to know how the trend of cheating cases is compared to the previous tests. The course instructor Saied that they had course for second year management students and they knew the student highly attempted in cheating but this strategy minimize level of cheating compared to the pervious time. According to their response cheating cases are reduced and minimized as compared to the previous testes.

\section{Conclusion}

As the study finding indicates that student highly attempted in cheating but this strategy minimize level of cheating compared to the pervious time, however cheating is not avoided, even the student know there was a cod on exam and the supervision of the invigilators cheating cases are reduced and minimized as compared to the previous testes.. From this finding the researcher conclude that coding as exam cheating minimization mechanism plays a vital role. But it became effective when there is series supervision and implementations of different method of exam cheating preventions before and during the exam started. Finally the researchers faced different problems during the implementation and evaluations of the proposed strategies. Those are Lack of accessibility of free class rooms for invigilation, Some instructors were reluctant and non-cooperative for shading and coding their exam and Even though students were instructed not to bring their cell phone, they brought it to the exam rooms that are mainly due to the fear of thief or the absence a secured rooms.

\section{REFERENCE}

[1] UNESCO. (1998). The UNESCO report of educational quality. UNESCO.

[2] Teixeira, A. a. (2008). An empiricalexplanation of Academic cheating in Spain and Portugal. :International Journal of Iberian Studies.

[3] Jordan, A. E. (2001). The role of motivation, perceived norms, attitudes, and knowledge of institutional policy." Ethics \& Behavior, ,. College student cheating", 11 (, 11 (3)).

[4] Sarita and Dahiya, R. ( 2015). Academic cheating among students: pressure of parents andteachers. International Journal of Applied Research

[5] Nath, L. a. (2008). Cheating on multiple choice exams monitoring and assessment. College cheating, , Vol. 57/ (No. 1.).

[6] Mary's, S. (2006). Students' Experiences with Academic Cheating.

[7] Patton, Q. a. (2002). A Guide to using qualitative research methodology. A Guide to using qualitative research methodology.

[8] Murdock, T. B. (2006, ). "Motivational perspectives on student cheating: Toward an integrated model of academic dishonesty.". Educational Psychologist, , 3 (41). 